\title{
Genesis of noble metal mineralization (Ag, Au, PGE) on the example of pechenga structure (Kola Peninsula)
}

\begin{abstract}
The problem of the genesis of noble metal (Ag, Au, PGE) mineralization in the Norther Pechenga zone is discussed, where these ores are associated with the classical $\mathrm{Cu}-\mathrm{Ni}$ deposits of Pechenga Ore Field. This mineralization is based on three main factors: subalkaline magmatism under conditions of compression, feeding of platform depressions with carbonaceous matter and basalt-silica splitting of magmas under conditions of liquid immiscibility. Considered geochemical aspects of this process. Briefly characterized vein deposits of noble metals in the Souther Pechenga zone.

The purpose of the article. The purpose of the article is to draw the attention of geologists to a possibly wide range of deposits of noble metals and diamonds, the genesis of which is associated with basalt-silica splitting under conditions of liquid immiscibility. Eruptive breccias of such deposits are often described by geologists as terrigenous rocks and conglomerates.
\end{abstract}

Volume 3 Issue 3 - 2019

Skuf'in P
Apatity, Geological Institute Kola SC RAS, Russia

Correspondence: Skuf'in P,Apatity, Geological Institute Kola SC RAS, Russia, Email skuf@geoksc.apatity.ru

Received: May 17, 2019 | Published: June 28, 2019

\section{Introduction}

In the earth's crust, gold has a close affinity with a pleiad of elements - the closest "neighbors" in the Periodic Table - Fe, Co, $\mathrm{Ni}, \mathrm{Pt}, \mathrm{Pd}, \mathrm{Os}, \mathrm{Ir}, \mathrm{Ru}, \mathrm{Rh}$. In the Pechenga structure, these elements, which, together with $\mathrm{Au}$ and $\mathrm{Ag}$, have formed complex $\mathrm{Cu}-\mathrm{Ni}$-noble metal deposits are associated with basite-hyperbasite magmas, the genesis of which is due to the fluid melting of the mantle substrate under the influence of deep-seated hydrogen-containing overheated solutions (fluids). In this case, the noble metal mineralization is based on three main factors: subalkaline magmatism under conditions of compression, feeding of platform depressions with carbonaceous matter and basalt-silica splitting of magmas under conditions of liquid immiscibility in basalt or picrobasalt melt. In addition to the classic Pechenga deposits of the gabbro-wherlite formation, a typical example is the Bragino Au-PGE deposit in the Souther Pechenga zone, for which sub-alkaline magmatism of a wide range of compositions is also typical, as well as the enrichment of sedimentary rocks with carbonaceous matter.

At present, it is known ${ }^{1}$ that ore-bearing fluids can be represented as substances of the $\mathrm{C}-\mathrm{H}-\mathrm{O}$ system, with the release of simple substances $\left(\mathrm{O}_{2}, \mathrm{H}_{2}, \mathrm{H}_{2} \mathrm{O}, \mathrm{C}, \mathrm{CO}, \mathrm{CO}_{2}, \mathrm{CH}_{4}\right)$. In this case, the paragenesis of simple substances are divided into 2 families - watercarbon dioxide and water-methane. Water-carbonic fluids arise in the situation of the stretching of the earth's crust, which reduces the fluid pressure in the system due to the migration of hydrogen from the fluids as the most mobile component. This leads to the generation of water-carbon dioxide fluids, according to the reaction:

$$
\mathrm{H}_{2}+2 \mathrm{CO}=\mathrm{H}_{2} \mathrm{O}+0.5 \mathrm{CO}_{2}+1.5 \mathrm{C}
$$

The water-carbon dioxide fluids are aggressive with respect to the $\mathrm{Si}-\mathrm{Al}$ granite-gneiss basement, which is leached under their influence, which leads to the development of large depressions, which are subsequently filled with basalt lavas. At the time of the rift stretching of the basement of the Pechenga structure, these phenomena led to the initiation of a large Ludia-Kalevia trough filled with tholeitic lavas of the Zapolyarny and Matert suites (Figure 1). The formation of Cu-Ninoble metal deposits is associated with the subsequent two stages of the evolution of tectonic-magmatic processes - the stage of deposition of powerful (up to $1.5 \mathrm{~km}$ ) carbonaceous sediments of the Productive Suite and the final stage of sub-alkaline volcanism-magmatism, which occurs in a compression environment of the Earth's crust. The formation of gabbro-wehrlites is associated with a powerful local compression stage against the background of general rift tension. ${ }^{2}$

More than 300 intrusive massifs of the gabbro-wehrlites, much of which contain rich sulfide $\mathrm{Cu}-\mathrm{Ni}$ mineralization, with accompanying noble metals (Ag, $\mathrm{Au}, \mathrm{PGE})$, have penetrated into sedimentary rocks of the Productive Suite in this final stage. On the schematic map, the location of the penetrated intrusions is shown by a double dotted line (Figure 1). Hydrogen migration from ore-bearing fluids at the same stage slowed down, and its prevalence over oxygen components was restored according to the reaction: $4 \mathrm{H}_{2}+2 \mathrm{CO}=2 \mathrm{H}_{2} \mathrm{O}+\mathrm{CH}_{4}+\mathrm{C}$. As a result, the water-methane evolution of fluids led to sub-alkaline intrusive and effusive magmatism of gabbro-wehrlite composition.

\section{The results of the study}

A peculiar and in many ways unique rocks of the Pechenga volcanic section is an association of silica-enriched rhyolites and ultra-silica volcanites (kagusites), established among volcanites and the NorthernPechenga Zone, and the Southern-Pechenga Zone. ${ }^{3}$ The sub-alkaline tholeiites of the lower part of the Matert Suite include a differentiated rock horizon (DRH) with a thickness of $200 \mathrm{~m}$, which is composed of a wide range of lavas and tuffs - alkaline Ti-basalts, rhyolites, and ultra-silica volcanites (kagusites). The genesis of this association of differentiates is associated with the liquidation phenomena of liquid immiscibility in magmas of picrite-basalt composition. In this horizon, characteristic structural relationships of picrites, basalts and their differentiats in the variolite lavas composed of Fe-basalt globules 
in a picrite-basalt matrix are established. Various body shapes of eruptive breccias and lava-breccias with a contrasting composition of debris in the picrite-basalt matrix are noted. Table 1 shows the average compositions of these rocks. Analysis of the geochemical features of subalkaline differentiates of DRH reveals the features of their formation (Table 1, analyzes 1-17). The petrochemical diagram (Figure 2A), compiled from differentiates of DRH and volcanites of Matert Suite, gives a general scheme for the formation of the main types of volcanites of the Matert Suite, and in particular, the rocks of DRH. The structural relationships between picrites and basalts are clearly expressed in variolites composed of basalt globules in a picritic matrix (analyzes 5 and 6). The compositions of these rocks in the petrochemical diagram (Figure 2B) are connected by line-connode, emphasizing their origin in connection with the development of liquid immiscibility in melts. This diagram shows the combination of two trends for impurity elements in the considered magmatic differentiated complex: hyperbasite $(\mathrm{Cr}+\mathrm{Co}+\mathrm{Ni})$, which is most pronounced in picrites (analyzes 7 and 9), and alkaline $(\mathrm{Ba}+\mathrm{Si}+\mathrm{Rb}$ ), represented not only in alkaline basalts (analysis 1), but also in kagusites (analysis 13). Along with ultra-silica rocks - kagusites (analyzes 13-17) - the composition of the complex under consideration includes silica-rich Na-rhyolites and ignimbritic rocks of rhyolite composition (analyzes 11 and 12).

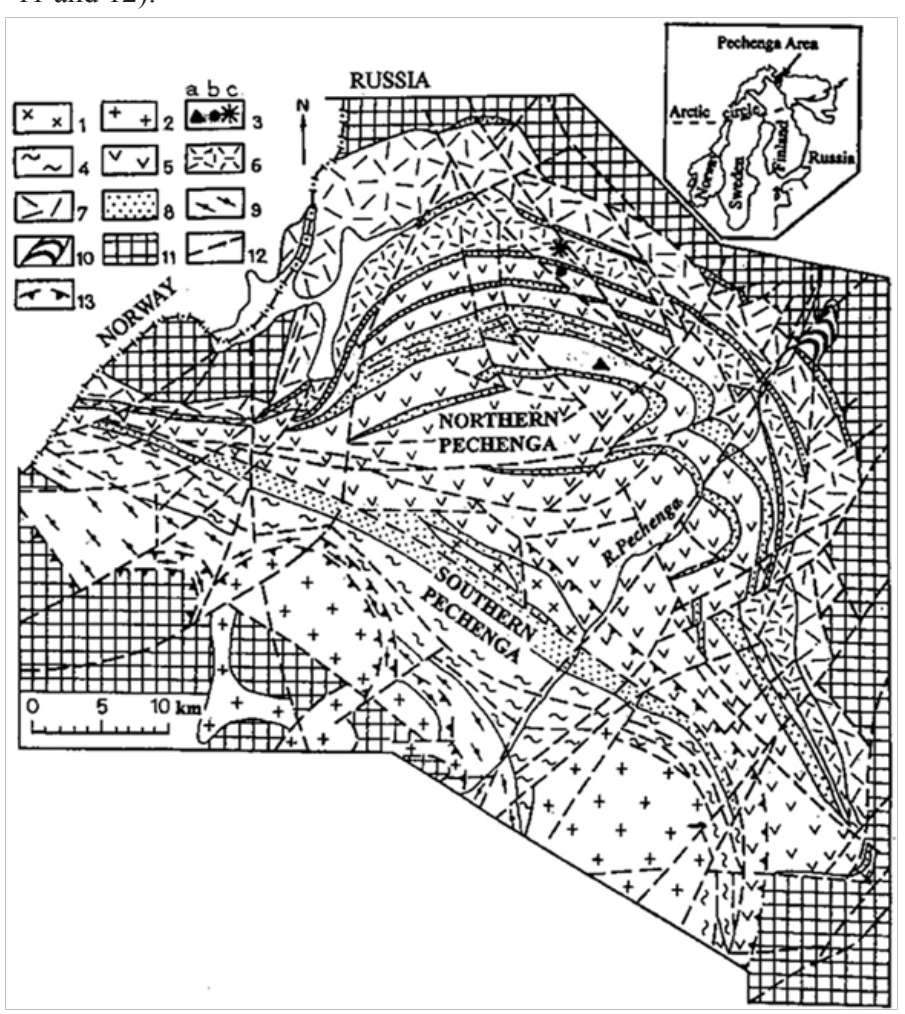

Figure I Schematic geological map of the Pechenga structure. Legend: I, Subvolcanic dacitic intrusions of Poritash Complex; 2, Plagio-microcline granites; 3, Position of the Kola Superdeep Borehole (a) and structural boreholes IX (b) and X (c); 4, Volcano-sedimentary rocks of the SouthernPechenga Zone (absolute age - 1940-1700 Ma); 5-8, volcano-sedimentary rocks of the Northern-Pechenga Zone (absolute age - 2220-1940 Ma): 5, Tholeitic lava of the Zapolyarny (in the north) and Matert (in the south) Suites; 6, Volcanites of the Pirttiyarvi Suite; 7,Volcanites of the Mayarvi Suite; 8, Sedimentary formations separating the formations of volcanic rocks; 9 , Archean gneisses; 10, Basaltic intrusion of the General-Mountain; I I, Archean basement; I2, Faults; I3, Large thrusts.

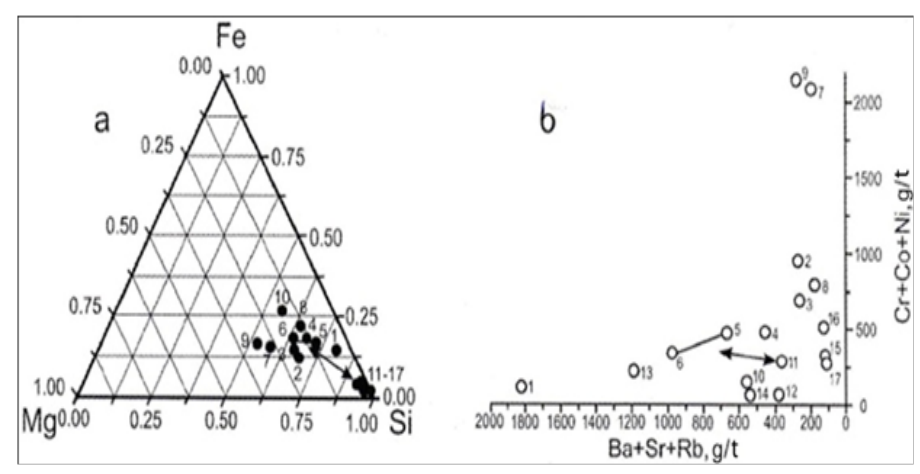

Figure 2(A) The scheme of formation of volcanic rocks of DRH (numbers numbers of analyzes in Table I);

(B) The splitting of alkaline $(\mathrm{Rb}+\mathrm{Sr}+\mathrm{Ba})$ and ultrabasic $(\mathrm{Cr}+\mathrm{Co}+\mathrm{Ni})$ volcanites between the kagusites and the volcanic rocks entering the $\mathrm{DRH}$. Line-connodes and diverging arrows indicate magmatic splitting, according to Figure 2(A).

Thus, dominant basaltic melts of high alkalinity, enriched in $\mathrm{Rb}$ and strong bases ( $\mathrm{Ba}$ and $\mathrm{Sr}$ ), were split into picrites (analysis 10), on the one hand, and silica-rich magmas (analysis 11-17) on the other. Silica-rich magmas in turn were split into rhyolitic and kagusitic, sometimes almost pure quartz melts (analysis 17), which remained in the magmatic system in contrasting liquid immiscibility with basic and acidic magmas. According to the composition of alkali metals, kagusites are divided into plumasitic potassium (analyzes 16,17) and agpaitic sodium (analysis 15) types. It should be noted that the process of formation of liquivant eruptive breccias and lava-breccias with a contrasting composition of debris and picrite-basalt matrix definitely models the process of formation of the ore-bearing gabbro-wehrlite formation of the Pechenga structure as a whole. It was established ${ }^{3}$ that on the border of the Productive Suite with overlapping basalts of Matert Suite, there are powerful horizons of picrite tuffs and tuffbreccias associated with the volcanic centers of picrite volcanism and in spatial and temporal connection with intrusions of Fe-picrites and massifs of gabbro-wehrlite formations.

It is to these eruptive centers that not only areas of powerful emissions of tuff material are confined, but also the formation of the richest sulfide $\mathrm{Cu}-\mathrm{Ni}$ ores in gabbro-wehrlites. Intrusions of gabbrowehrlites often contain unusual structures for intrusive rocks, such as amygdaloid, variolitic, spinifex, etc. In these rocks there is a wide presence of glassy phases, as well as a weak sintering of surrounding phyllites. Therefore, at present, a number of researchers often defend the idea of Pechenga ore-bearing intrusions as hypabyssal or even lava formations. The alkali-metal melts, rich in $\mathrm{S}, \mathrm{F}, \mathrm{Cl}$, have a selective chemical affinity for ore metals, including gold. Gold has low solubility in acidic and neutral solutions, but with the transition to alkali-metal medium, its solubility increases dramatically due to the formation of easily soluble monovalent and trivalent compounds $\mathrm{KAu}(\mathrm{HS})_{2}, \mathrm{KAuO}_{2}, \mathrm{KAuS}_{2}$. This effect, proved for hydrothermal solutions, ${ }^{4}$ can also be applied to alkali-metal ultra-silica melts containing "free" alkali metals that are not bound into aluminosilicate structures.

The alkaline (alkali-metal) nature of ultra-acid lavas is due to a decrease in $\mathrm{Al}_{2} \mathrm{O}_{3}$ in their composition, with a deficiency in which in these rocks instead of feldspar and mica, alkaline hydroxides $\mathrm{K}(\mathrm{OH})$ and others arise, as well as the corresponding sulfide and 
halide complexes. At the same time, the solubility of ore metals, including noble ones in liquid quartz melts with their high alkalimetal nature, is much higher than their solubility in silicate melts and in transmagmatic liquids, which are distinguished by low solubility in them of ore metals. Quartz ore deposits are formed on this basis, incl. and in the Pechenga structure, characterized by a wide distribution and diversity of metallic ores (the Bragino deposit in the South Pechenga zone). Quartz melts, which are practically free of aluminum, best meet this condition, representing the most favorable environment for effective gold extraction from silicate melts. As emphasized in, ${ }^{4}$ this extraction played a major role in the formation of gold quartz veins.
In combination with the agpaitic character of fluid quartz melts, this factor can contribute to the formation of large ore noble metal deposits. At the same time, peculiar eruptive breccias are formed, which form ore bodies of complex shape at depth or, during explosive volcanic eruptions, are ejected onto the surface like tagamite or suvit melts of explosive pseudo-astroblems. It can be considered that similar gas-melt tuff-like mixtures are very mobile and under high pressure can form not only mantle sediments of the "watershed pebble" type, but also penetrate through cracks far into host rocks in the form of injection intrusive tuffs.

Table I Chemical compositions (wt.\%) and impurity elements $(\mathrm{g} / \mathrm{t})$ of volcanics of the Matert Suite and rocks of the DRH-horizon

\begin{tabular}{|c|c|c|c|c|c|c|c|c|c|c|c|c|c|c|c|c|c|}
\hline $\begin{array}{l}\text { Compo- } \\
\text { nents }\end{array}$ & I & 2 & 3 & 4 & 5 & 6 & 7 & 8 & 9 & 10 & II & 12 & 13 & 14 & 15 & 16 & 17 \\
\hline & $n=1$ & $n=2$ & $n=3$ & $n=35$ & $n=6$ & $n=6$ & $n=6$ & $n=4$ & $n=4$ & $n=2$ & $n=2$ & $n=21$ & $n=2$ & $n=2$ & $n=I$ & $n=I$ & $n=I$ \\
\hline $\mathrm{SiO}_{2}$ & 47.18 & 48.61 & 47.62 & 48.04 & 49.07 & 44.44 & 41.89 & 42.49 & 41.92 & 40.21 & 74.39 & 74.7I & 80.78 & 82.24 & 86.1 & 83.92 & 94.73 \\
\hline $\mathrm{TiO}_{2}$ & 3.49 & 1.61 & 1.51 & 1.85 & 3.57 & 3.94 & 2.08 & 1.78 & 2.18 & 0.11 & 0.19 & 0.39 & 0.74 & 0.19 & 0.51 & 0.27 & 0 \\
\hline $\mathrm{Al}_{2} \mathrm{O}_{3}$ & 12.67 & 12.29 & 13.42 & 13.05 & 11.16 & 11.52 & 7.6 & 12.3 & 10.43 & 15.88 & 11.17 & 10.07 & 7.03 & 7.05 & 3.22 & 2.73 & 0.34 \\
\hline $\mathrm{Fe}_{2} \mathrm{O}_{3}$ & 4.04 & 6.01 & 2.21 & 3.66 & 4.41 & 3.62 & 3.65 & 5.45 & 3.42 & 5.6 & 0.21 & 0.99 & 0.5 & 0.51 & 1.18 & 1.21 & 0.53 \\
\hline $\mathrm{FeO}$ & 6.56 & 5.38 & 10.56 & 12.1 & 9.88 & 11.96 & 10.39 & 12.82 & 12.91 & 17.76 & 4.2 & 4.03 & 3.16 & 2.91 & 3.75 & 1.29 & 1.78 \\
\hline $\mathrm{MnO}$ & 0.24 & 0.18 & 0.22 & 0.2 & 0.16 & 0.19 & 0.17 & 0.2 & 0.24 & 0.2 & 0.03 & 0.06 & 0.03 & 0.04 & 0.06 & 0.04 & 0.01 \\
\hline $\mathrm{MgO}$ & 2.08 & 8.75 & 9.01 & 6.2 & 5.17 & 8.38 & 12.95 & 5.96 & 16.16 & 8.3 & 1.42 & 0.89 & 1.11 & 0.32 & 1.77 & 1.36 & 0.18 \\
\hline $\mathrm{CaO}$ & 8.51 & 7.44 & 6.61 & 8.17 & 9.54 & 10.32 & 11.28 & 11.77 & 6.63 & 0.34 & 0.6 & 1.4 & 1.03 & 0.82 & 0.98 & 3.41 & 0.8 \\
\hline $\mathrm{Na}_{2} \mathrm{O}$ & 2.1 & 3.87 & 2.42 & 2.98 & 2.89 & 1.34 & 0.13 & 0.38 & 0.19 & 0.82 & 4.29 & 2.62 & 1.79 & 0.64 & 0.09 & 1.5 & 0.1 \\
\hline $\mathrm{K}_{2} \mathrm{O}$ & 4.21 & 0.92 & 1.69 & 0.25 & 1.5 & 1.19 & 0.06 & 0.16 & 0.23 & 1.93 & 1.69 & 3.02 & 2.44 & 4.03 & 0.01 & 0.14 & 0.03 \\
\hline $\mathrm{H}_{2} \mathrm{O}^{-}$ & 0.56 & 0.11 & 0.46 & 0.39 & 0.22 & 0.19 & 0.24 & 0.33 & 0.32 & 0.57 & 0 & 0.15 & 0 & 0.12 & 0.25 & 0 & 0.06 \\
\hline $\mathrm{H}_{2} \mathrm{O}^{+}$ & 3.37 & 3.42 & 4.01 & 2.85 & 1.92 & 2.52 & 5.17 & 5.05 & 4.89 & 8.03 & 1.27 & 1.02 & 1.01 & 0.74 & 2.05 & 1.66 & 0.35 \\
\hline $\mathrm{P}_{2} \mathrm{O}_{5}$ & 0.48 & 0.12 & 0.11 & 0.15 & 0.38 & 0.4 & 0.18 & 0.12 & 0.2 & 0.01 & 0.02 & 0.05 & 0.14 & 0.02 & 0 & 0.19 & 0 \\
\hline $\mathrm{CO}_{2}$ & 4.02 & 0.25 & 0.1 & 0.11 & 0.02 & 0.06 & 4.32 & 0.65 & 0.3 & 0.31 & 0.45 & 0.17 & 0.15 & 0.35 & 0.26 & 2.13 & 0.59 \\
\hline Stot & 0.2 & 1.22 & 0.15 & 0.11 & 0.34 & 0.04 & 0.12 & 0.55 & 0.06 & 0.1 & 0.1 & 0.16 & 0.24 & 0.05 & 0 & 0.02 & 0.4 \\
\hline$\Sigma$ & $\begin{array}{l}99 . \\
71\end{array}$ & $\begin{array}{l}100 . \\
18\end{array}$ & $\begin{array}{l}100 . \\
1\end{array}$ & $\begin{array}{l}100 . \\
11\end{array}$ & $\begin{array}{l}100 . \\
23\end{array}$ & $\begin{array}{l}99 . \\
94\end{array}$ & $\begin{array}{l}100 . \\
23\end{array}$ & $\begin{array}{l}100 . \\
01\end{array}$ & 100.13 & 100.12 & 100.03 & 99.73 & 100.15 & 100.03 & 100.23 & 99.87 & 99.9 \\
\hline $\mathrm{Rb}$ & 71 & 10 & 30 & 30 & 25 & 31 & 6 & 4 & 24 & 40 & 16 & 85 & 44 & 90 & 2 & n.det. & n.det. \\
\hline $\mathrm{Sr}$ & 517 & 118 & 130 & 130 & 110 & 140 & 150 & 90 & 190 & 50 & 140 & 55 & 91 & 35 & 40 & n.det. & n.det. \\
\hline $\mathrm{Ba}$ & 1240 & 140 & 100 & 100 & 530 & 800 & 40 & 80 & 60 & 460 & 210 & 240 & 1050 & 410 & 80 & n.det. & n.det. \\
\hline $\mathrm{Ni}$ & 41 & 400 & 200 & 200 & 150 & 140 & 800 & 200 & 950 & 60 & 60 & 30 & 120 & 15 & 100 & n.det. & 100 \\
\hline Co & 11 & 50 & 90 & 90 & 50 & 55 & 85 & 90 & 95 & 50 & 45 & 5 & 15 & 5 & 10 & n.det. & 10 \\
\hline $\mathrm{Cr}$ & 58 & 500 & 400 & 400 & 270 & 140 & 1200 & 500 & 1100 & 20 & 180 & 25 & 85 & 45 & 400 & n.det. & 190 \\
\hline
\end{tabular}

Note: I-I7, Volcanites of Matert Suite: I, alkaline basalt; 2,3, Alkaline picrobasalt (2) and alkaline picrobasalt (3) from the eruptive breccia of kagusit-basaltic composition, respectively; 4, Lower basalt of the Matert Suite; 5,6, Globules (5) and matrix (6) from Fe-picrobasaltic globular lava; 7, Lower ferropicrit of the Matert Suite; 8-17,Volcanites of the DRH-horizon: 8.9 - volcanites from the eruptive breccia: low-alkaline ferrobasalt (8) and picrite (9); I0-I3,Volcanites from tuff fragments (I0 - eucrite, II, I2 - rhyolite, I3 - kagusit), I4 - lava of kagusitic composition; I5 - kagusit from lavobreccia fragments; I6-I7 - kagusites from the fragments of eruptive kagusit-basaltic breccia.

I.I. Dorofeeva ${ }^{5}$ in the survey work on gold-bearing and diamondbearing "watershed pebbles" listed the most characteristic signs of such sediments: placement of isolated large areas of "pebbles" at various hypsometric levels of the paleo-relief; a close resemblance to pebble compositions from various regions of the world (quartz pebbles, sometimes described as quartz bonds). Ore mineralization is usually confined to the cementing material. The thickness of such deposits is variable and varies from 0.5 to many tens of meters. Rocks resemble mud deposits characteristic of high mountain areas, but they are not, being developed in platform conditions. Gold and diamond "watershed pebbles" are exploited in Africa, Australia, S. America, Brazil, India, Indonesia. Usually, alluvial, proluvial, fluvioglacial, glacial, and other processes are involved in their formation. The pseudo-clouding of the detrital material and the nature of sediment 
placement often force geologists to draw precisely such conclusions, but none of the exogenous processes can explain the features of such pseudoconglomerates. These deposits are characterized by the presence of rounded (melted?) Fragments of minerals with large melting temperature gradients: diamond, zircon, pyrochlore, monazite, sphene, rutile, tourmaline, moissanite, magnetite ore balls, native zinc and iron.

\section{Conclusion}

Perhaps now the geological community is on the verge of a significant discovery - the largest gold, platinum, uranium and diamond deposits of our planet are not sedimentary and not hydrothermal formations, but are connected at certain stages of the tectonic-magmatic evolution of mountain systems with basaltsplitting of magmas under conditions of liquid immiscibility.

\section{Acknowledgments}

None.

\section{Conflicts of interest}

The authors declares that there is no conflicts of interest

\section{References}

1. Marakushev AA, Marakushev SA. PT-facies of simple, hydrocarbon and organic substances of the system C-H-O. DAN. 2006;406(4):521-527.

2. Skuf'in PK. Volcanism of the Kola region (Part I). Ancient PechengaVarzuga Greenstone Belt. LAP LAMBERT Academic Publishing. Saarbrucken. 2014;368.

3. Marakushev AA, Skuf'in PK. Basalt-kagusitic cleavage of lavas of Early-Proterozoic Pechenga Structure on the Kola Peninsula. DAN. 2008;419(5):1-5.

4. Dadze TP, Kashirtseva GA. Experimental study of the solubility of gold in sulfide-containing hydrothermal solutions. Collection Experimental mineralogy, M Science. 2004;315-326.

5. Dorofeeva II. About the origin of some types of diamondiferous watershed pebbles. Izv Universities Geol and razv. 1963;19-25. 